\title{
A IMUNIDADE DOS GOVERNANTES NO DIREITO INTERNACIONAL*
}

\author{
THE IMMLNITY OF RULES IN INTFRNATIONAL LAW
}

\author{
Daniel Damásio Borges ${ }^{-*}$ \\ Gauthier Vannieuwenhuyse.*.
}

\begin{abstract}
Resumo:
A imunidade dos governantes é um preceito bem assente no Direito Internacional, em que pesem a incerteza das suas fontes normativas e as mudanças ocorridas em sua fundamentação. A imunidade tem por objetivo proteger o livre exercicio da função de governante no interesse do Estado por ele dirigido. Todavia, essa regra clássica do Direito Internacional tem sido posta em causa pela tendência contemporânea de combate à impunidade cm matéria de crime internacional.
\end{abstract}

Palavras-chave: Imunidade. Governantes. Crimes Internacionais, Impunidade.

\begin{abstract}
:
The immunity of the rules in international law is a very well established norm in international law, even tough its sources are uncertain and its justifications have been changed. The purpose of the immunity is to protect the autonomy of rulers in the interest of the State which is represented by them. However, this classical norm of international law has become very controversial nowadays because of the fight against the impunity that surrounds international crimes.
\end{abstract}

Keywords: Immunity. Rules. International crimes. Impunity.

A imunidade dos governantes sempre foi considerada um preceito bem sedimentado no Direito Internacional: segundo Robert Jennings, tal preceito é tão antigo quanto o próprio Direito Internacional, ${ }^{1}$ o que comprova a sua necessidade para a comunidade interestatal. Contudo, paradoxalmente, a imunidade parecia uma norma de tal modo evidente que ela jamais foi objeto de convenções internacionais e a doutrina negligenciou, em grande medida, esse tema até o célebre caso Pinochet, em 1998. Ademais, a imunidade dos governantes tem sido cada ver mais posta em causa pela

Este artigo è a versão traduzida e revista do trabalho apresentado sobre a imunidade dos governantes no curso de Muster Recherche (2005-2006) em Direito Internacional da Universidade de Paris I (PanthéonSorbonne).

. Mestre em Direito Internacional pela Faculdade de Direito da USP e titular do diploma Master Recherche em Direito Internacional pela Universidade de Paris I (Panthéon-Sorbonnc).

-. Graduado em Direito pela Universidade de Paris X (Nanterre) e titular do diploma Master Recherche em Direito Internacional pela Universidade de Paris I (Pantheon-Sorbonne)

I JENNINGS, Robert. The Pinochet Extradition Case in the English Courts. In: BOISSSON DE CHAZOURNES, L.; GOWLLAND-DEBBAS (eds). The International legal system in quest of equity and equality: Liber amicorum Georges Abi-Saab. Nijhoff, The Hague, 2001, p. 684-685. 
tendência contemporânea de responsabilização dos governantes por atos cometidos em violação ao Direito Internacional.

A imunidade é, assim, uma regra bem estabelecida no Direito Internacional, porém bastante controversa e que comporta diferentes aspectos, de sorte que se fala indistintamente em imunidade e em imunidades dos governantes. Um de seus aspectos menos contestados consiste na inviolabilidade pessoal que protege os governantes em visita an estrangeiro contra medidas coercitivas (a prisão ou detenção, por exemplo) e contra ofensas à sua pessoa e à sua dignidade. ${ }^{2} \mathrm{~A}$ imunidade de jurisdição permite ao governante subtrair-se a um processo judicial diante dos tribunais de um Estado estrangeiro. A imunidade de execução, por seu turno, consiste na proibição das vias de execução de jurisdições estrangeiras contra a pessoa e os hens dos governantes.'

O objeto deste estudo consiste precisamente na análise dessas imunidades dos governantes, o que exclui, por conseguinte, as imunidades dos Estados e dos diplomatas. No Direito Internacional, inexiste uma definição da categoria de governantes. Todavia, admite-se que os chefes de Fstado e de Governo e o ministro das Relações Fxteriores possam ser identificados como governantes e, em conseqüência, sejam protegidos pelas imunidades. ${ }^{4}$

As imunidades jamais foram concebidas com o objetivo de proteger os interesses pessoais dos governantes. Ao revés, essa proteção especial que lhes é conferida é justificada pelo papel preponderante por eles exercido no seio de seus Estados e na condução das relações internacionais. São, pois, os interesses do Estado de ver os seus governantes desempenharem sem ingerência externa e de modo independente as suas funções e os da comunidade intemacional de ver as relações internacionais desenrolaram-se de modo estável e ordenado, que são protegidos pelas imunidades. No entanto, as imunidades são por vezes consideradas como sinònimas de impunidade, porquanto o óbice processual que elas apresentam pode tornar-se uma exoneração de facto da responsabilidade internacional dos governantes. Ora, o interesse atual da comunidade internacional é o de ver os autores de crimes internacionais punidos. o que se choca com a regra clássica das imunidades quando os governantes estão implicados

Veja-se, a esse respeito, 0 an. $1^{\circ}$ da resoluçào do Instituto de Dircito Internacional de 26 de agosto de 2001: "la personne du chel d'Etat est inviolable sur le territoire d'un ltat étranger. Elle ne pcut ètre soumise à aucune forme darrestation ou de détention. Lés autorités de celui-ci traitent le chef d Fitat avec lc. respect qui lui est dû et prennent toutes mesures raisonnables pour empècher qu'il soit porté atteinte à sa personne ou sa dignité". Annuaire de l'institut du óroit intemational. p. 742. 2000-2001/69.

Como afirma C. Dominice. a imunidade consiste em "un obstacle de procédure qui fait obligation au juge de refuser de statuer sur une requéte qu il a normalement compétence de connaitre." DOMINICE (C.). Quelques observations sur l'immunité de juridiction pénale de l'ancien chel d’Etat. Revue Générale de Droit Intimational Public. p. 299. 1999/2.

Nós voltaremos a abordar a questão dos beneficiários das imunidades na primeira parte deste artigo. 
na comissãu de crimes internacionais. A luta contra as violações dos direitus humanos e contra os crimes internacionais tornou-se uma prioridade para a comunidade internacional, como demonstra o desenvolvimento do Direito Internacional dos Direitos Humanos, do Direito Internacional Penal e do Direito Internacional Humanitário. O equilíbrio entre esses interesses, por vezes em oposição, é precário.

Assim, na primeira parte deste artigo, mostrar-se-á que a imunidade é um preceito necessário ao livre exercício da função de governante no interesse do Estado (l) e, em uma segunda parte, que ela coloca obstáculos à luta contra a impunidade em matéria de crime internacional (2).

I A imunidade: um preceito necessário ao livre exercício da função de governante no interesse do Estado

A imunidade é uma regra estabelecida de longa data no Direito Internacional, ainda que as suas fontes sejam incertas (1.I). Tal preceito jamais foi absoluto e de aplicação irrestrita. São os interesses do Estado c a estabilidade das relações internacionais que são tutelados pelas imunidades. Assim, os governantes não se beneficiam das imunidades quando os atos por eles perpetrados não colocam em causa o Estado (1.2).

1.1. Um preceito bem estabelecido no Direito Internacional, mas de fontes incertas

O fundamento das imunidades dos governantes evoluiu e adaptou-se às mudanças da sociedade internacional (1.1.1). Mas se é verdade que este preceito sempre foi considerado como uma evidência no Direito Internacional, não é menos certo que as suas fontes são paradoxalmente incertas (1.1.2).

\section{I.I.I. A evolução do fundamento das imunidades}

\subsubsection{O fundamento antigo: a confusão entre a soberania estatal e a figura do governante}

Historicamente. as primeiras teorias buscam justificar as imunidades dos governantes e mais particularmente as dos chefes de Estado (sejam eles reis. imperadores ou príncipes) com base no caráter sagrado de seu estatuto. Com efeito, à época, atribuia-se a Deus a origem dos poderes e da legitimidade dos soberanos. No século XVII, Hennig Arnisaeus escrevia que os soberanos. na qualidade de titulares da 
majestas (o poder soberano), não podiam ser julgados por nenhum tribunal terrestre e eram responsáveis apenas diante Deus. ${ }^{5}$ Essa corrente de pensamento encontrou respaldo até o fim do século XIX. Carlo Francesco Gabba afirmava, por exemplo, que a qualidade de soberano "era uma qualidade inerente à pessoa do chefe de Estado, que nela penetra completamente, de sorte que o príncipe é sagrado e inviolável em todas as manifestações de sua atividade" "Contudo, a Revolução francesa marcou o declínio dessa teoria e as imunidades do chefe de Estado passaram a serem justificadas pelo princípio da igualdade soberana dos Estados.

Até a Revolução francesa, a personificação do poder era de tal ordem que era difícil separar o Fstado do individuo que nele ocupava o cargo de cúpula mais elevado e atribuía-se ao chefe de Estado os mesmos privilégios inerentes ao próprio Estado. A soberania estatal estava absorvida pela pessoa designada pelo qualificativo de "soberano" o que é significativo da atribuição pessoal da soberania.? Assim, as imunidades do Estado consubstanciavam-se nas imunidades de seu órgão máximo. ${ }^{8}$ As imunidades dos chefes de Estado apresentavam-se, assim, como o corolário do princípio da igualdade soberana entre os Estados, consoante o qual nenhum Estado e, por assimilação, nenhum soberano não estava apto a julgar e a ser julgado pelo seu par, o que é explicitado pelo adágio par in parem non habet imperium. Sendo a justiça pronunciada $\mathrm{em}$ nome do soburano, não se podia admitir que um tribunal de um país pudesse pronunciar um julgamento contra um soberano estrangeiro.

Fssc adágio foi com freqüência repetido pela doutrina e pela jurisprudência até o início do século XX, mas o titular da imunidade passou a ser o próprio Estado, sujeito de Direito Internacional. e não mais o soberano. Pela assimilação do chefe de Estado a esse último, atribuiu-se àquele a imunidade de que o próprio Estado era titular. Submeter o chefe de Estado à justiça do Estado estrangeiro era considerado como uma violação da soberania estatal. Assim, a Corte de Alger, em 1914, afirmou que:

seguindo um principio de Direito Internacional
universalmente admitido, os soheranos e chefes de Estado
participam da independência do Estado de que são
representantes. Estando colocados por assim dizer acima
das leis do Estado estrangeiro. eles não podem estar

Amisaeus, Liv. I, Ch III., n. 5 apud. BORGHI, A. L'immunité des dirigeants politiques en droit international. Helbing \& Lichtenbahn. Genève, 2003. p. 44.

6. "(...) étail une qualité inhérente à la personne du chef d'Etat, qui la pénètre complètement, de sorte que le prince est sacré et inviolable dans toutes les manifestations de son activité" GABBA, F. De la compétence des tribunaux à l'égard des souverains et Etats étrangers. Journal du Droit International, p. 36. 1888/15.

7 PANCRACIO, J. P. L'évolution historique du statut de chef d’Etat. In: Société Françaisc pour le Droit International. Le chef d'Etat et le droit international. Pedone, Paris, p. 15.

8 DECAUX, E. Les gouvemants. In: ASCENSIO, H.; DECAUX, E.; PELLET, A. (eds). Droit international pénal. Pedone, Paris. 2000. p. 183. 
submetidos a nenhuma jurisdição a não ser aquela de sua própria nação."

\section{I.I.2. O fundamento funcional moderno}

Atualmente, afirma-se que o fundamento das imunidades é puramente funcional..$^{10}$ É para proteger o livre exercício das funções de govcrnante e, por conseguinte, para tutelar os interesses do Estado por ele dirigido, que o governante não pode ser submetido a uma jurisdição estrangeira cuja autoridade repousa na soberania de um outro Fstado. A Corte Internacional de Justiça no caso Yerodia" chancelou esse entendimento: “(...) no Direito Internacional consuetudinário, as imunidades reconhecidas ao ministro das relações exteriores não thes são conferidas pura u sua vantagem pessoal, mas para lhes permitir cumprir livremente as suas funções por conta do Estado por ele representado" 12 É, assim. o Estado representado que é protegido pelas imunidades de seu governante. A esse propósito. cumpre ressaltar que, na qualidade de titular desse direito, o Estado pode a ele renunciar. ${ }^{17}$ O governante, por sua vez, não sendo o titular desse direito, não pode dele dispor a título pessoal e deve obter a anuência do Estado para poder a ele renunciar.

É também o interesse da comunidade interestatal que é tutelado pelas imunidades. uma vez que sem elas o desenvolvimento das relações internacionais pode ser comprometido. Com efeito. o questionamento das ações dos governantes pelas jurisdições estrangeiras pode ser prejudicial à manutenção de boas relações diplomáticas entre os Estados, tanto mais que tais processos podem ser motivados por fins políticos. A

9 “(...) suivant un principe de droit international universellement admis. les souverains et chefs d`Etat participent de l'indépendance de l’Etat dont ils sont les représentants. Que placés en quelque sorte audessus des lois de tout Etat étranger. ils ne peuvent ètre soumis à aucune juridiction autre que celle de leur propre nation". Ben Aiad c. Bey de Tunis. Cour d'Alger, arrèt du 12 janvier 1914. Journal du Droil International, p. $1.291,1.914 / 41$.

10 WATTS, A. The legal position in internatiunal law of heads of states, heads of governments and forcign ministers. Recueil des Cours de l'Académie de Droit International de l'Haye, p. 102-103, 1994/247.

"O litigio opôs a Bélgica à República Democrática do ('ongo na Corte Internacional de Justiça. Em reação ao mandado internacional de detenção. emitido pula justiça belga. contra o então ministro das Relações Exteriores congolês Abdoulaye Yerodia Ndombasi. a República Democrática do Congo questionou na Corte a legalidade desse mandado. $\mathrm{O}$ mandado judicial belga fundava-se nos crimes de gucrra c contra a humanidade atribuidos a Yerodia. Como veremos ulteriormente, a alta jurisdição internacional reconheceu a imunidade de Yerodia e considerou ilegal o mandado judicial em apreço.

12 “ (...) en droit international coutumier. les immunités reconnues au ministre des affaires étrangères ne lui sont pas accordées pour son avantage personnel, mais pour lui permettre de s acquitter librement de ses fonctions pour le compte de l'Etat qu'il représente." Afraire du mandat d'arrèt du 11 avril 2000, C.I.J., 14 février 2002, § 53.

13. VERHOEVEN, J. L'immunité des organes des sujets de droit international. In: VERHOEVEN, J. (ed.). Le droil international des immunités: contestation ou consolidation?. L.G.D.J. Paris, 2004. p. 112. 
esse respeito, os juizes Higgins, Kooijmans e Buergenthal sublinharam, em sua opinião conjunta no Caso Yerodia, que:

o direito dos privilégios e das imunidades mantém a sua importância uma vez que as imunidades são atribuídas a altos funcionários públicos para garantir o apropriado funcionamento da rede de relações mútuas interestatais. o que é de suprema importância para um sistema internacional bern ordenado e harmonioso. ${ }^{14}$

Essa abordagem funcional das imunidades dos governantes tem por conseqüência a extensão da categoria dos seus beneficiários, porquanto ela rompe a unidade conceitual que existia entre o Estado e o seu dirigente supremo: o chefe de Estado. Assiste-se. desde a segunda metade do século XX. à multiplicação dos representantes do Fstado. que têm por função representá-lo e vinculá-lo nas matérias afeitas à sua competência. A título de exemplo, o papel conferido aos ministros de pastas de matérias técnicas no seio do Conselho da União Furopéia é emblemático dessa evolução. () tema da extensão dos beneficiados das imunidades dos governantes fundada no interesse da função é, portanto, colocado.

Se não restam dúvidas de que os chefes de Fstado e de governo são protegidos pelo Direito Internacional, o caso do ministro das Relações Exteriores foi muito contestado até a decisão da Corte Internacional de Justiça do Caso Yerodia, a qual afirmou claramente a natureza consuetudinária da imunidade do ministro das Relações Exteriorss. ${ }^{15} \mathrm{O}$ acórdão da Corte pode firmar um precedente para a extensão dos beneficiados das imunidades para outros membros do governo. Assim, mutatis mutandis, nada se opõe que um outro membro do governo beneficie-se da mesma imunidade do ministro das Relações Exteriores, quando ele é chamado a exercer no estrangeiro funções internacionais. ${ }^{16}$

Por conseguinte, malgrado a evolução do fundamento das imunidades dos governantes, elas permanecem sendo um preceito bem sedimentado no Direito Internacional e necessário para os Lstados. Entretanto, paradoxalmente, as suas fontes continuam sendo incertas.

\footnotetext{
it " $(\ldots)$ the law of privileges and immunities retains its importance since immunities are granted to high states officials to guarantec the proper functioning of the network of mutual inter-State relations, which is of paramount importance for a well-ordered and harmonious international system". Joint Separate Opinion of Judges Higgins, Kooijmans et Buergenthal. \$ 75.

is Affaire du mandat d'arrêt du 11 avril $2000, \S 53$.

16 VERHOEVEN (J.). op. cit, p. 2.
} 


\subsubsection{O caráter incerto das fontes convencionais e consuetudinárias}

\subsubsection{As lacunas das fontes convencionais e consuetudinárias}

A origem consuetudinária das imunidades dos governantes foi reafirmada em diferentes decisões judiciárias, a exemplo, no Direito francês, da decisão da Corte de Cassação no ('aso Kadhafi. ${ }^{17}$ e da Corte Internacional de Justiça no Caso Yerodia, muito embora essa última não tenha demonstrado em seu acórdão a prática e a opinio iuris deste costume. No entanto, o número muito limitado de casos de aplicação do preceito da imunidade na prática internacional tende a tornar o conteúdo e os contomos das imunidades incertos, notadamente no que se refere à identificação dos órgãos dos Estados beneficiados pelas imunidades.

A prática internacional é essencialmente formada pelas legislações nacionais e pela jurisprudência. Ora. somente três países dispõem de uma legislação que trata especificamente das imunidades dos governantes e mais particularmente dos chefes de Estado: ${ }^{18}$ o Reino Unido com o State Immunity Act. a Austrália com o lioreign Sovereign Immunities Act e a Índia cujo código de processo civil aborda esse tema em seu art. 86.

Os juizes desses três países baseiam-se principalmente nas suas legislações internas para decidir se us chefes de Estado estrangeiros estão protegidos pelas imunidades. o que não contribui para a formulação de uma regra costumeira internacional. A Alta Corte de Bombay, por exemplo, afirmou em um acórdão. de 17 de março de 1955, que: "qualquer que seja o principio do Direito Internacional, nós estamos interessados na forma legislativa que ele assumiu em nosso pais" 1 "

Ademais. a jurisprudência é rara e relativamente antiga ${ }^{20}$ o que resulta. na expressão de Michel Cosnard. ${ }^{21}$ em um patchwork incompleto e dificilmente explorável para se enunciar uma regra geral acerca das imunidades dos governantes.

Quanto às fontes convencionais. não existe nenhum tratado internacional que discipline de uma maneira geral a imunidade dos governantes e que fixe o regime aplicável. Todavia, há uma convenção internacional que aborda esse tema em um quadro

17 Arêt du 13 mars 2001 concernant l'immunité du chef d’Etat lybien Muammar Kadhafi. Bulletin Cour de Cassation, ch. Crim., n. OO-87.215, p. 218.

18 COSNARD, M. I.es immunités du chef d`Etat. In : Société Française pour le Droit International. Le chef d'Etat et le droit international. Pedone, Paris, p. 223-224.

19 "(...) whatever the principle of international law may be, we are concerned with the statutory form that it has taken in our country". Maharaj Indrajitsinghji Vijaysinghi v. Maharaja Rajendrasinghi Vijaysinghi. Indc, High Court of Bombay, 17 mars 1955. International law reports. p. 246. 1958/22.

20 WATTS, A. op. cit., p 19.

21 COSNARD, M. op. cit., p. 223-224. 
específico: a Convenção, de 8 de dezembro de 1969, sobre as missões especiais. Essa convenção é aplicável aos chefes de Estado, às personalidades de posição elevada que se encontram no estrangeiro em visita oficial e àqueles que chefiam a delegação. Entretanto, essa convenção pouco esclarece o regime das imunidades, porquanto ela própria faz um reenvio ao Direito consuetudinário, cujos limites já foram salientados. Assim, o art. 21 I I da convenção afirma que o chefe de Estado, quando chefia a missão especial, beneficia-se das facilidades, privilégios e imunidades reconhecidos pelo Direito Internacional aos chefes de Estado em visita oficial. O parágrafo segundo do mesmo artigo prescreve a aplicação do regime consuetudinário das imunidades aos chefes de governo, ao ministro das Relações Exteriores e a outras personalidades de posição elevada. Diante dessas lacunas, uma parte da doutrina preconiza saná-las pela aplicação por analogia das fontes aplicáveis às imunidades dos diplomatas e dos Estados.

\subsubsection{A busca de fontes pela analogia}

Uma das soluções vislumbradas para se fazer face a essas lacunas é a aplicação por analogia do regime previsto para os diplomatas, visto que o governante é o representante natural de seu Fstado. Nessa ordem de idéias, os preceitos previstos pela Convenção de Viena, de 18 de abril de 1961, sobre as relações diplomáticas seriam estendidos a fortiori aos governantes, pois não se poderia conceber que um governante seja menos protegido que um outro representante hierarquicamente inferior e com menor prestígio. ${ }^{22}$ Essa solução foi acolhida pelos Estados que dispõem de uma legislação interna sobre as imunidades do chefe de Estado estrangeiro. Ela possui também o mérito da clareza, uma vez que as imunidades dos diplomatas são objeto de uma convenção internacional que codifica o costume acerca desse tema.

As situações de um governante e de um diplomata são, contudo, fundamentalmente distintas: os diplomatas encontram-se permanentemente sobre 0 território estrangeiro, ao passo que o governante nele se acha apenas timporariamente e seus poderes de representação são qualitativamente diferentes. Além disso, o diplomata é somente protegido contra a jurisdição do Estado estrangeiro em cujo território ele exerce as suas funções, enquanto que o governante desfruta de uma proteção bem mais vasta, uma vez que ele deve ser protegido contra as jurisdições de todos os Estados estrangeiros. Não se pode, pois, aplicar de modo estritamente idêntico o regime das imunidades dos diplomatas aos governantes.

22 COSNARD, M. op. cit., p. 237. 
Uma outra possível fonte para as imunidades dos governantes é o regime das imunidades do próprio Estado. Assim, no século XIX. o Instituto do Direito Internacional preconizava a aplicação do regime da imunidade dos Estados para os chefes de Estado. ${ }^{23}$ Essa posição encontra, ainda, certo respaldo nos dias de hoje. Lord Goff of Chieveley, na terceira decisão do caso Pinochet, afirmou que: "O principio da imunidade do Estado é expresso na máxima latina par in parem non habet imperium, o qual tem por conseqüencia a regra de que nenhum Estado adjudica a condula de um outro. Esse principio aplica-se tanto entre os Estados, e o chefe de Estado é titular da imunidade do Estado tal como o próprio Estado, quanto para os representantes diplomáticos do Estado" ${ }^{24}$ Mais recentemente, o projeto de artigos, de 1991, da Comissão de Direito Internacional sobre as imunidades jurisdicionais dos Estados e de seus bens contém em seu art. $3^{\circ}$ uma disposição que faz referência aos chefes de Estado, mas tal artigo não tem por finalidade fundar a aplicação do projeto aos chefes de Estado ¿ nem precisar a extensão de seu estatuto. ${ }^{25}$

Não-obstante, a analogia entre os Estados e scus governantes não é isenta de censuras. Com efeito, tal analogia ignora a diferença de natureza entre uma pessoa fisica e uma entidade abstrata, além de não levar em consideração a distinção moderna entre o Estado e a figura de seu governante. Ela não leva em conta, também, o regime ratione temporis das imunidades dos governantes, em virtude do qual a extensão da proteção é menor quando o governante não exerce mais as suas funções. ${ }^{26}$ Além disso, determinados processos são próprios às pessoas fisicas (o contencioso em matéria de Direito de Familia e de Direito Penal, por exemplo). $\dot{E}$, assim, pouco plausivel procurar no regime das imunidades do Estado uma fonte aplicável de modo idêntico aos governantes.

Em que pese a incerteza sobre o valor das fontes da imunidade dos governantes, a vocação desse instituto jurídico é clara: a de proteger a função de governante e por trás dela o Estado representado. É esse fundamento que fixa os limites das imunidades dos governantes: os atos que não colocam em causa o Estado são excluídos da proteção conferida pelas imunidades.

COSNARD. M. op. cit. p 241.

25 "The principle of state immunity is expressed in the Latin maxim par in parem non habet imperium, the effect of which is that one sovereign state does not adjudicate on the conduct of another. This principle applies as between states, and the head of a state is entitled to the same immunity as the state itself, as are the diplomatic reprisentatives of the state" Lord Goff of Chieviley, Affaire Pinochet de 24 de março de 1999. International Legal Material. p. 598, 1999/37.

25 BORGHI, A. L'immunité des dirigeants politiques en droit international. Genève, Helbing \& L_ichtenhahn, 2003, p 68.

26 COSNARD, M. op. cit., p 241 . 
1.2. A limitação da imunidade dos governantes: a exclusão dos atos que não colocam em causa o Estado

\subsubsection{A limitação clássica ratione temporis da imunidade dos governantes}

\subsubsection{A imunidade dos governantes em exercício}

Os governantes em exercício são protegidos por dois tipos de imunidades que se sobrepõem durante o periodo em que ocupam os seus cargos públicos: a imunidade ratione materiae e a imunidade ratione personae.

A imunidade ratione personae abrange atos que não se enquadram no exercício das funções dos governantes e as condutas que tenham sido consumadas antes mesmo que o governante tenha iniciado a exercer as suas funções oficiais. ${ }^{27}$ Isso não significa dizer que ela seja absoluta. A esse respeito, convém distinguir a imunidade de jurisdição civil que é limitada, da imunidade de jurisdição penal e da inviolabilidade que permanecem sendo absolutas.

Em se tratando da imunidade civil, as fontes não são claras, pelo que é necessário recorrer à analogia. cujos limites já foram salientados. A convenção sobre as relações diplomáticas, de 1961. prevê restrições à imunidade em matéria de ações reais imobiliárias, de sucessão, de atividade comercial e de ação reconvencional. Ademais, a convenção, de 1969. em seu art. 31 § 2 afasta a imunidade em caso de ação por reparação de danos advindos de um acidente ocasionado fora do exercício das funções oficiais. Essas restrições apenas se aplicam quando se trata de atos privados. ${ }^{2 \gamma}$ No Caso Yerodia, a imunidade de jurisdição civil não estava em causa. Todavia, cumpre lembrar que a Corte Internacional de Justiça sublinhou que as imunidades outorgadas ao ministro das Relações Exteriores the eram concedidas para que pudesse exercer livremente as suas funções por conta do Estado por ele representado. ${ }^{29}$ Por conseguinte, quando o exercício da jurisdição não se acompanha de medidas coercitivas sobre o governante, as quais possam impedir-lhe de exercer as suas funções, é duvidoso estender-se o caráter absoluto da imunidade penal à imunidade civil. Como salienta J. Verhoeven, ${ }^{30}$ é excessivo afirmar-se que a mera manifestação de autoridade - a qual constitui o exercício da jurisdição civil -- contra o governante é, em si mesma, incompatível com o livre exercício de suas funções.

BORGHI. A. op. cit., p. 53.

VERHOEVEN, J. op. cit, p. 75

Affaire du mandat d'arrêı du 11 avril 2000, op. cil. \$53.

VERHOEVEN. J. op. cir. p. 77. 
Contrariamente à imunidade de jurisdição civil, a imunidade de jurisdição penal e a inviolabilidade são absolutas. Elas justificam-se pela necessidade de permitir aos governantes o desempenho de suas funções sem que eles sejam objeto de medidas coercitivas. Tal observação foi, aliás, realirmada pela Corte Internacional de Justiça no Caso Yerodia. ${ }^{31}$

Contudo. a manutenção da natureza absoluta da imunidade de jurisdição penal é hoje questionada, quando o governante em exercício é acusado de crimes internacionais (nós voltaremos a abordar esse tema na segunda parte deste artigo).

Quanto à imunidade ratione materiac dos governantes, que abarca unicamente os atos cometidos no exercício de suas funções, ela começa a produzir efeitos somente quando eles deixam o seu cargo público.

\subsubsection{A imunidade funcional dos ex-governantes}

A abordagem funcionalista em que se funda a concepção moderna das imunidades implica uma limitação do alcance desse instituto jurídico. Tais imunidades não se aplicam do mesmo modo ao governante em exercício e ao ex-governante que se tornou uma pessoa privada: nesse último caso, não apenas os tribunais estrangeiros podem se pronunciar sobre os atos ulteriores ao término do excrcicio da função de governante, como também eles podem julgar retroativamente determinados atos perpetrados durante tal exercício. ${ }^{32}$

Convém ressaltar, todavia, que a imunidade ratione materiae outorgada aos ex-governantes justifica-se também pelo fundamento funcional: os atos ligados ao desempenho das funções de governante não podem ser postos em causa por eventuais processos judiciais movidos após o término do exercício de tais funçôes. Conforme observa J. Verhoeven, uma ameaça, mesmo que virtual, de processos judiciais que

" "(..) si un ministre des affaires étrangères est arrêté dans un autre Etat à la suite d'une quelconque inculpation, il se trouvera à l"évidence empêché de s"acquitter des tâches inhérentes à ses fonctions. Les obstacles ainsi apportés à l'exercice de telles fonctions officielles ont des conséquences aussi graves, que le ministre des affaires ćtrangères, au moment de son arrestation, ait été présent à titre officiel ou privé sur le territoire de l'Etat ayant procédé à cette arrestation, que celle-ci concerne des actes qu'il aurait accomplis avant d'occuper le poste de ministre des affaires étrangères ou des actes accomplis dans le cadre de ses fonctions, ou encore qu 'elle conceme des actes qu 'il aurait accomplis à titre 'officiel' ou des actes qu'il aurait accomplis à titre 'privé'. En outre, le simple fait qu'en se rendant dans un autre Etat ou qu'en traversant celui-ci un ministre des affaires étrangères puisse être exposé à unc procédure judiciaire peut le dissuader de se déplacer à l'étranger lorsqu'il est dans l'obligation de le faire pour s'acquitter de ses fonctions". Affaire du mandat d'arrêt du II avril 2000, C.I.J., \$ 54-55.

32 DECAUX, L. Le statut du chef d'Etat déchu. Annuaire Français de Droit Intemational, p. 101. 1980. 
seriam movidos após o término de suas funções, é suficiente para incitar o governante a não as exercer com a independência requerida. ${ }^{33}$

Assim, os ex-governantes apenas se beneficiam da imunidade ratione materiac e não da imunidade ratione personae. Isso significa dizer que o ex-governante ¿́ protegido apenas por aquilo que se relaciona aos atos de função e não, por conseguinte, aos atos efetuados a título privado. Nesse sentido, a imunidade ratione materiae é menos protetora que a ratione personae, muito embora a primeira perdure mais no tempo.

Em virtude dessas características da imunidade ratione materiae dos exgovemantes, avulta a importância da seguinte indagação: quais são os critérios que devem ser utilizados para se qualificar uma determinada conduta como sendo um ato de função.

\subsubsection{As incertezas quanto à distinção entre atos de função e atos privados}

\subsubsection{A busca de uma definição de atos de função no direito das imunidades do Estado e dos diplomatas}

A noção de ato de função é fugidia e complexa, ${ }^{i 4}$ de modo que não há na doutrina nem na jurisprudência uma definição unânime do seu conceito. A isso se acresce que nenhuma convenção internacional disciplina essa questão. Faz-se necessário, por isso, buscar subsídios adicionais, para traçar a tênue fronteira entre os atos de função e os atos privados, no direito das imunidades do Estado e dos diplomatas.

Em se tratando das imunidades do Estado, tornou-se corrente distinguirem-se os atos soberanos (acta jure imperii) dos atos realizados pelo Estado que poderiam ser feitos por um particular (acta jure gestionis). ${ }^{35}$ Essa distinção, contudo, pouco esclarece a noção de ato de função. O governante, no exercício de sua função e em nome do Estado, pode realizar tanto um ato de gestão (firmar um contrato administrativo de fornecimento de bens, por exemplo) quanto um ato de soberania (assinar um decreto regulamentado una lei ou ordenar um ato de polícia, por exemplo). Do mesmo modo, o governante pode utilizar-se das prerrogativas de sua função em benefício próprio tanto no exercício de atos de gestão quanto no desempenho de atos de soberania. Por conseguinte, o recurso à analogia não é pertinente nesse caso, pois ele não possibilita estabelecer o conteúdo dos atos de função.

Quanto à imunidade dos diplomatas. a prática nessa matéria é um ponto de referência importante para distinguir os atos de função dos atos privados no direito das

\footnotetext{
33 VERHOEVEN, J. op. cit., p. 99.

34 SALMON, J. Immunités el actes de la fonction. Annuaire Français de Droit Intemational, p. 357, 1992.

35 Veja-se, por exemplo, BORGHI. A. op. cit. p. 8.
} 
imunidades dos governantes, ainda que ela não traga uma definição clara do conceito de atos de função. Com efeito, a jurisprudência não é pacífica no que diz respeito a casos que envolvam abusos de função dos diplomatas para fins pessoais e atos que sejam considerados ilícitos para o Estado acreditado, mas cometidos com a anuência do Estado acreditante.

Sobre o tema, Jean Salmon aponta diferentes critérios para qualificar um ato de função: a forma do ato, a qualidade em que o agente realizou o ato, as formas utilizadas pelo agente quando ele cumpriu o ato objeto da demanda, a existência de uma autorização preambular, a presença de instruções oficiais, a aprovação ulterior dada por uma autoridade hierárquica superior, todo outro indício sobre a intenção do agente de agir de boa-fé no quadro do exercício de suas funções. ${ }^{36} \mathrm{~A}$ análise de Salmon tem o mérito da exaustividade, porém não permite afirmar qual é o critério preponderante. $O$ uso de diferentes critérios de qualificação dos atos de função pode conduzir a resultados opostos: por exemplo, se a forma de um determinado ato pode ser oficial, a sua finalidade pode ser o enriquecimento pessoal e configurar, sob esse ponto de vista, um desvio de função. Por isso, é mister escolher um critério preponderante para se qualificar uma conduta de ato de função.

\subsubsection{As incertezas quanto à distinção entre atos privados e atos de função no direito das imunidades dos governantes}

Podem-se identificar dois tipos de abordagem na definição dos atos de função na doutrina e na jurisprudência. A primeira, por nós designada pelo qualificativo "formalista", procura identificar os atos de função pela forma que eles assumem. Assim, um ato que possua a forma oficial ou, de um modo mais geral, de Direito Público (um decreto, uma portaria, um contrato administrativo, por exemplo), seria um ato de função. A contrario sensu, um ato realizado pelo governante que não assuma tal forma seria considerado um ato privado. o que impediria tal governante de beneficiar-se, quando deixasse o seu cargo público, da imunidade ratione materiae no que diz respeito aos processos relacionados a esse ato.

Sob esse prisma, o caráter oficial do ato -- determinado em função da forma que assumiu - não seria afetado pela sua ilicitude do ponto de vista da legislação do Estado do foro ou do Fstado do governante. Foi o que afirmou, notadamente, a Corte Federal de Apelação estadunidense do nono circuito no caso Republic of Philippines $v$. Marcos de 4 de junho de 1987 Esse último litígio tratou de uma demanda proposta pelo

36 SALMON, J. op. cit. p. 314-357. 
Governo filipino após a fuga do ex-presidente Marcos, que visava a recuperar os bens e recursos financeiros que teriam sido desviados em benefício do ex-presidente e de sua esposa. A jurisdição norte-americana considerou que os atos cometidos por uma autoridade governamental eram atos oficiais, e a fortiori quando tais condutas assumiam a forma de leis, decretos, portarias ou outro ato governamental..$^{3^{-}}$Ademais, o tribunal norte-americano afirmou que a ação proposta pelo Governo filipino opunha-se à doutrina do act of state, consoante a qual um ato administrativo ou legislativo estrangeiro deve ser tido como válido mesmo se ele repugna aos princípios juridicos do Estado de foro. ${ }^{38}$

Um diferendo similar opôs o Governo haitiano ao seu ex-presidente JeanClaude Duvallier. Mais uma vez, tratava-se da recuperação de fundos públicos desviados pelo ex-governante quando do exercício de suas funções. A Corte de Cassação francesa rejeitou o pedido do Haiti de recuperação de tais fundos e afirmou que os litígios acerca das relações entre um Estado e seus dirigentes estão necessariamente relacionados ao exercício do poder público. ${ }^{39}$

Assim, segundo essa jurisprudência. atos que vão claramente de encontro ao interesse do próprio Estado podem ser considerados atos de função, desde que assumam a forma oficial. A escolha desse critério formalista tem amplas repercussões nos processos. envolvendo os crimes patrimoniais dos ex-governantes. Com efeito. os atos em torno de tais crimes tomam com freqüência a forma oficial. À guisa de exemplo. pode-se citar um decreto que institui um monopólio ou ainda um contrato administrativo de obras públicas que não tenham outro objetivo senão o de organizar um sistema de corrupção em benefício do governante. Esse excessivo apego à forma do ato e a desconsideração da sua finalidade, na identificação dos atos de função, motivaram muitas críticas da doutrina ${ }^{40}$.

Essa não é, todavia, a única abordagem adotada para se identificarem os atos de função. Há, também, uma segunda abordagem, por nós qualificada de finalista, a qual se centra mais no objetivo que o ato visa a alcançar que na sua forma. Nessa ordem de idéias, para que uma conduta seja considerada um ato de função, ela deve ter por escopo contribuir efetivamente para o exercício da função de governante e não-atender a uma finalidade puramente privada. Assim, observa S. Wirth, ${ }^{41}$ se uma medida do

37 Republic of the Philippines v. Marcos, 818 Federal Reporter. $2^{\text {nd }}$ series, p. 1473.

38 Sobre a conhecida doutrina norte-americana do act of state, ver BORGHI. A. op. cit. p. 479 e W.ITTS. A. op. cit., p. 59.

39 Consorts Duvalier et autres c. Etat haïtien et autrcs. Arrêt de la Cour de Cassation. 29 mai 1990. Journal du Droil International, p. 139-140, 1991:118.

* Veja-se, por exemplo. WATTS, A. op. cit, p. 60.

4 WIRTH (S.). Immunity for Crimes? The IC I's Judgement in the Congo v. Belgium ('ase. European Journal of Intemational I aw. p. 890, 2002//3. 
governante que tenha por objetivo restaurar a segurança e a ordem pública pode ser considerada um ato de função, uma conduta cujo escopo seja o enriquecimento pessoal do governante deve ser qualificada como um ato privado.

Essa abordagem finalista também encontra guarida em decisões de jurisdições nacionais. Ela foi acolhida, por exemplo, pela Corte Federal norte-americana do quinto circuito no caso Jimenez 1 : Aristeguieta, de 1962. O litígio versou sobre o pedido de extradição feito pela Venezuela aos EUA sob o fundamento das acusações de desvio de fundos públicos que pesavam sobre o ex-chefe de Estado Jimenez. Em seu julgamento, o tribunal norte-americano afirmou que os atos imputados a Jimenez constituíam crimes financeiros que foram perpetrados em violação à posição por ele ocupada de chefe de Fstado e não em conformidade com essa última. ${ }^{42}$

Fssa qualificação de crimes patrimoniais como atos privados é bastante significativa do estreito liame entre a defesa dos interesses do Estado e o instituto jurídico da imunidade dos governantes: condutas que não colocam em causa o Estado e que são mesmo contrárias ans interessús desse último não são protegidas pelas imunidades.

Não-obstante, não é possível, no estado atual do Direito Internacional, identificar-se uma definição consensual dos atos de função, diante das incertezas acima apontadas. Convém ressaltar, porém. que se a imunidade ratione materiae abrange apenas os atos de função, isso se dá para se tutelarem os interesses do Estado. A abordagem finalista inscreve-se, por isso, na perspectiva funcional das imunidades dos governantes e responde às exigências da comunidade internacional de luta contra a impunidade. visto que ela restringe o rol de condutas que não é suscetivel de ser apreciado pelo juiz estrangeiro.

A imunidade dos governantes é, assim, um preceito paradoxal: os Estados sempre o consideraram como uma regra fundamental e necessária para a estabilidade das relações internacionais, ainda que a incerteza reine em se tratando de suas fontes e da distinção fundamental entre ato de função e ato privado. Se a diferenciação entre atos de função e atos privados fundada na proteção do interesse do Estado sempre foi determinante para traçar os contornos das imunidades dos governantes, novos limites perfilam-se e encontram a sua justificação em um outro interesse: o da comunidade internacional de ver os autores de crimes internacionais julgados e punidos.

42. Jimenez v. Aristeguieta (5th circuit). 313 Federal Reporter. $2^{\text {nd }}$ series, p. 557. 
2. A imunidade dos governantes face à luta contra a impunidade em matéria de crime internacional ${ }^{43}$

A proteção de que os governantes desfrutam no exercício de suas funções em razão de suas imunidades tem dado causa, com certa freqüência, à comissão de graves violações ao Direito Internacional pela utilização do aparelho do Estado, em particular no domínio dos Direitos Humanos.

O regime clássico das imunidades choca-se, assim, com a tendência atual do Direito Internacional em priorizar a proteção dos direitos fundamentais dos individuos, notadamente pela consagração da responsabilidade penal individual por violações aos direitos humanos. Nesta segunda parte, convém abordar dois aspectos dessa evolução: a qualificação como crime internacional de determinadas condutas relacionadas ao exercício da função de governante (2.l) e a afirmação da responsabilidade individual dos governantes pela perpetração de crimes internacionais (2.2).

2.1. O impacto sobre as imunidades da criminalização de atos relacionados ao exercício da função de governante

Um número apreciável de crimes internacionais está estreitamente relacionado ao exercício da função de governante, uma vez que tais crimes apenas podem ser cometidos por meio do controle sobre o aparato estatal. Tais são os casos, por exemplo, das violações ao direito humanitário e da tortura. ${ }^{+4}$

Daí a importância do estudo da repercussão da criminalização de determinadas condutas pelo Direito Internacional sobre as imunidades de que desfrutam os governantes. Os termos dessa questão colocam-se de modo diferente quando se trata da imunidade racione materiae dos ex-governantes (2.1.1) e quando se aborda a imunidade racione personae dos governantes que ainda estão no desempenho de suas atribuições (2.1.2).

4 São considerados crimes intemacionais aqueles previstos pelo art. $5^{\circ}$ Estatuto da Corte Penal internacional, vale dizer: o crime de genocidio, os crimes contra a humanidade, os crimes de guerra e o crime de agressão. Todavia, conforme o próprio referido artigo reconhece, não há ainda uma definição do crime de agressão. Nesse último caso, conformc prevè o parágrafo segundo do art. $5^{\circ}$, a Corte será apenas competente para conhecer desse crime quando houver a sua tipificaçâo.

$\therefore \quad$ A esse propósito, Michel Cosnard observa. com razão, que: "Il est souvent affirmé, non sans raison que les règles pénales internationales visent au premier chef les gouvernants. les titulaires du pouvoir, puisque, compte tenu de leur ampleur et de leur gravité. seuls les plus hauts responsables peuvent matériellement en être les auteurs, que ce soit au stade de la planification ou de l'exćcution à grande échelle. D'ailleurs, l'ensemble du projet de code des crimes contre la paix el la sćcurité internationale de la CDI reposait sur limplication de l'appareil étatique dans la commission des crimes" COSNARD (M.), op. cit., p. $227-228$. 


\subsubsection{A influência da criminalização de condutas ligadas ao exercício da função de governante sobre a imunidade ratione materiae dos ex-governantes}

\subsubsection{Os crimes internacionais como atos privados}

Como já vimos, a noção de atos de função, cujos contornos são extremamente difíceis de serem demarcados com precisão, ${ }^{45}$ constitui o ponto fulcral para delimitar-se a imunidade ratione materiae dos ex-governantes. Esse tema torna-se tanto mais problemático quanto a delimitação dessa imunidade pode pôr em causa a política oficial, ainda que não explicitamente admitida, de um Estado. Em outros termos, torma-se ainda mais polêmica a qualificação de uma conduta criminosa como um ato privado quando tal conduta é cometida na defesa de uma suposta razão de Estado e não, como no caso dos crimes patrimoniais, para proteger interesses privados. O célebre Caso Pinochet diante da Câmara dos Lordes britânica é disso uma ilustração. ${ }^{46}$

Quando a alta jurisdição britânica apreciou pela primeira vez o pedido da Espanha de extradição do ex-chefe de Estado chileno Augusto Pinochet, ela considerou, por três votos contra dois, que o crime internacional da tortura, sobre o qual a demanda espanhola foi precipuamente fundada, não pertencia à categoria de atos de função.

Para os juizes britânicos, os crimes internacionais imputados a Pinochet eram atos privados, ainda que eles houvessem sido perpetrados por Pinochet na sua condição de chefe de Estado e fossem justificados pela política oficial do Estado chileno da época de combate aos oponentes políticos ao regime então vigente. Tal qualificação fundou-se no entendimento dos lordes britânicos de que a tortura não era uma atitude aceitável de um indivíduo, tanto menos de um governante, e não podia ser considerada, portanto, uma função do chefe de Estado. Nesse sentido, a imunidade prevista pelo Direito Internacional não podia dar guarida a essa sorte de condutas. Em um trecho muito significativo e contundente de seu voto, Lord Nicholls of Birkenhead afirmou que conceber a tortura como um ato de função seria ludibriar o Direito Internacional. ${ }^{47}$

\footnotetext{
45 A esse respeito, J. Verhoeven menciona "la part de mystère qui ne cesse d'entourer 'l'acte de la fonction." VERHOEVEN. J. op. cit., p. 102.

t. Antes do Caso Pinochel, o mesmo problema havia-se colocado em um caso envolvendo a imunidade civil ratione materiae de que os ex-governantes são titulares. Trata-se de uma ação por reparação de danos movida diante dos tribunais estadunidenses pelas vítimas de graves violaçốs de direitos humanos contra 0 ex-chefe de Estado filipino, Marcos. Em sua defesa, Marcos fez valer a imunidade rationc materiae de que é titular como ex-chefe de Estado. Em sua decisão, de 21 de outubro de 1992, a Corte de Apelação estadunidense do nono circuito rejeitou essa defesa, afirmando que atos de tortura e de assassinado não podem ser considerados atos oficiais. Para o tribunal norte-americano, os crimes de que Marcos era acusado iam alèm do que era permitido pelo Dircito filipino e deviam, por conseguinte, ser considerados atos privados. Para uma descrição em pormenor desse caso, ver BORGHI (A.), op. cit., p 68.
} 
Essa mesma posição sobre os crimes internacionais foi, aliás, reafirmada pelos juizes Higgins, Kooijmans e Buergental em sua opinião conjunta proferida no Caso Yerodia. ${ }^{48}$

Conforme observa Michel Cosnard, a finalidade de tal linha de raciocínio é clara: adotar-se uma concepção restritiva de atos de função. para tornar determinadas condutas suscetíveis de apreciação pelo juiz estrangeiro. ${ }^{49}$

Tal ponto de vista foi, todavia, criticado pelos lordes dissidentes e por uma parte importante da doutrina. ${ }^{40} \mathrm{~A}$ esse respeito, Lord Lloyd of Berwick sublinhou que os crimes imputados a Pinochet foram por ele cometidos na sua qualidade de chefe de Estado, porquanto foram perpetrados com a colaboração de outros governos e pela ação da polícia e do serviço secreto que ele dirigia na sua condição de governante. ${ }^{51}$ Ademais, pode-se objetar que a natureza oficial dos atos é um elemento constitutivo da própria definição de determinados crimes internacionais, em particular da tortura. ${ }^{52}$ Nessa ordem

47 " (...) it hardly needs saying that torture of his own subjects, or of aliens, would not be regarded by international law as a function of a head of state. All states disavow the use of torture as abhorrent, although from time to time some still resort to it. Similarly. the taking of hostages, as much as torture, has been outlawed by the international community as an offence. International law recognises, of course, that the functions of a head of state may include activities which are wrongful. eren illegal, by the law of his own state or by the laws of other states. But international law has made plain that certain types of conduct, including torture and hostage-taking, are not acceptable conduct on the part of anyone. This applies as much to heads of state, or even more so. as it does to everyone elsc: the contrary conclusion would make a mockery of international law." Lord Nicholls of Birkenhead. Judgment Regina v. Bartle and the Commissioner of Police for the Metropolis and others F.X Pare Pinochet (on appeal from a Divisional Court of the Queen's Bench Division) Regina v. Evans and another and the Commissioner of Police for the Metropolis and others EX Parte Pinochet (on appeal from a Divisional Court of the Queen's Bench Division). Decisão de 25 novembro de 1998. International Legal Materials, p. 1.312, 1998/37.

$\therefore \quad$ "(...) serious international crimes cannot be regarded as official acts because they are neither normal State functions nor functions that a State alone (in contrast to an individual) can perform." Joint Scparate Opinion of Judges Higgins, Kooijmans and Buergenthal, op. cit., $\$ 85$.

49 COSNARD, M. op. cil., p. 242.

so Veja-se, por exemplo. DOMINICÉ (C.), op. cil. p. 297- 308.

51 "Where a person is accused of organising the commission of crimes as the head of the government. in cooperation with other governments. and carrying out those crimes through the agency of the police and the secret scrvicc, the inevitable conclusion must be that he was acting in a sovereign capacity and not in a personal or private capacily." Lord Lloyd of Berwick. Judgment - Regina v. Bartle and the Commissioner of Police for the Metropolis and others E:X Parte Pinochet (on appeal from a Divisional Court of the Qucen's Bench Division) Regina v. Evans and another and the Commissioner of Police for the Metropolis and others EX Partc Pinochet (on appeal from a Divisional Court of the Queen's Bench Division). Decisão de 15 de novembro de 1998, op. cit., p. 1.315.

De acordo com o ant. $1^{\circ}$ da Convenção contra a torlura e todas outras formas de tratamento ou de penas cruéis. desumanas ou degradantes "Délinition de torture: tout acte par lequel une douleur ou des souftrances aiguës, physiques ou mentales, sont intentionnellement infligées à une personne aux fins notamment d'obtenir d'elle ou d'une tierce personne des renseignements ou des aveux, de la punir d'un acte qu'elle ou une tierce personne a commis ou esı soupçonnée d'avoir commis, de l'intimider ou de faire pression sur elle ou d'intimider ou de faire pression sur unc tierce personne, ou pour tout autre motif fondé sur une forme de discrimination quelle qu'elle soit. lorsqu'une telle douleur ou de telles souffrances sont infligées par un agent de la fonction publique ou toute autre personne agissanı à titre officiel ou à son instigation ou avec son consentement exprès ou tacite. Ce terme ne s'étend pas à la douleur ou aux 
de idéias, Michel Cosnard afirma que seria incoerente sustentar-se que a tortura seria um ato privado para se excluir a imunidade e, ao mesmo tempo, afirmar-se que ela seria um ato oficial para determinar a responsabilidade penal do governante. ${ }^{53}$

Essas objeções à caracterização do crime internacional como atos privados não nos parecem ser, contudo, determinantes. De início, cabe observar que o mero fato de o ex-governante ter praticado crimes internacionais fazendo uso de suas prerrogativas públicas não significa dizer que tais atos estejam protegidos pela imunidade ratione materiae. A ordem jurídica contemporânea, sobretudo pela afirmação do dever dos Estados de não-violar os Direitos Humanos, tem circunscrito as condutas que podem ser enquadradas como uma função do governante. Nesse sentido, atos que repugnam à ordem jurídica internacional, tais como os crimes internacionais, não podem ser considerados atos de função. Quanto à objeção de Cosnard acima referida, deve-se ter em mente os objetivos próprios das regras internacionais atinentes ao direito das imunidades. Se as normas acerca da responsabilidade internacional visam a identificar os indivíduos que praticaram os crimes internacionais e a responsabilizá-los penalmente, as normas sobre as imunidades têm por escopo proteger os governantes de processos relativos a determinados atos. Assim, dadas essas finalidades distintas, não nos parece de todo contraditório adotar-se uma concepção distinta de atos de função para cada ramo do Direito Internacional acima mencionado.

Essa interpretação extensiva dos atos privados não é, todavia, o único argumento a fundamentar a ausência da imunidade ratione materiae dos ex-governantes para crimes internacionais.

2.1.1.2. Os crimes internacionais como atos de função não-protegidos pela imunidade ratione materiae

Na terceira decisão da Câmara dos Lordes sobre o mesmo Caso Pinochet, ${ }^{54}$ a alta jurisdição inglesa admitiu que os atos de tortura atribuídos a Pinochet deveriam ser considerados atos de função. Uma das razões invocadas para justificar essa mudança de opinião foi precisamente a definição de tortura prevista na Convenção sobre a matéria, consoante a qual a tortura é necessariamente um crime cometido por uma autoridade oficial. ${ }^{55}$

souffrances résultant uniquement de sanctions légitimes, inhérentu's à cess sanctions ou occasionnées par elles"

33 COSNARD, M. op. cit., p. 249.

s4 A primeira decisão havia sido invalidada por uma segunda datada de 17 de dezembro de 1998. O mutivo de tal invalidaçâo foi o fato de Lord Hoffman. o juiz que havia dado o voto decisivo na primeira decisão. não ter revelado as suas ligações com a organização não-governamental Anistia Internacional, a qual intervicio no processo que redundou na primeira decisão.

ss Como sublinhou Lord Browne-Wilkinson: "Under the Convention the internatıonal crime of torture can only be committed by an official or someone in an official capacity" Lord Browne-Wilkinson. Judgment - 
Em que pese essa qualificação, os lordes ingleses decidiram que tal crime internacional não era suscetível de ser protegido pela imunidade ratione materiae. É dificil, contudo, identificar com nitidez a ratio decidendi desse julgado que trouxe uma inovação substancial para o direito das imunidades dos governantes. ${ }^{56} \mathrm{Em}$ uma decisão em que há tantos votos individuais quanto juízes, cada lorde expôs a sua própria fundamentação para negar a Pinochet a imunidade conferida a um ex-governante.

Pode-se afirmar, entretanto, que os lordes apoiaram-se, sobremodo, nas disposições da própria Convenção sobre a tortura, de 1984, para justificar a sua decisão. Em sua fundamentação que foi largamente seguida pelos outros juízes do caso, ${ }^{57}$ Lord Browne-Wilkinson afirmou que a Convenção sobre a tortura, de que o Chile e o ReinoUnido são partes, instituiu um sistema internacional para combatê-la. Assim, podia-se depreender de tal sistema convencional uma exceção, se bem que implícita. à imunidade dos ex-chefes de Estado, quando eles são acusados de haver cometido o crime de tortura. Concluir de outro modo, segundo o juiz britânico, seria contraditório com a finalidade

Regina v. Bartle and the Commissioner of Police for the Metropolis and Others Ex Parte Pinochet Regina v. Evans and Another and the Commissiuner of Police for the Metropolis and Others Ex Parte Pinochet (On Appeal from a Divisional Court of the Queen's Bench Division). International Legal Materials, p. 581 c s., $1999 / 38$.

56 A inovação que representava para o Direito Inturnacional a decisão dos juizes britânicos foi assinalada por Lord Browne-Wilkinson: "This is the point around which most of the argument turned. It is of considerable general importance internationally since, if Senator Pinochet is not entitled to immunity in relation to the acts of torture alleged to have occurred after 29 September 1988, it will be the first time so far as counsel have discovered when a local domestic court has refused to afford immunity to a head of state or former head of state on the grounds that there can be no immunity against prosecution for certain international crimes." Lord Browne-Wilkinson. Judgment Regina v. Bartle and the Commissioner of Police for the Metropulis and Others Ex Parte Pinochet Regina v. Evans and Another and the Commissioner of Police for the Metropolis and Others Ex Parte Pinochet (On Appeal from a Divisional Court of the Queen's Bench Division). Decisão de 14 de março de 1999. op. cit, p. 593.

37 Vejam-se, a esse respeito, os votos de Lord Hutton, Lord Millet, Lord Saville of Newdigate, Lord Philips of Worth Matravers. Judgment - Regina v. Bartle and the Commissioner of Police for the Metropolis and Others Ex Parte Pinochet Regina v. Fvans and Another and the Commissioner of Police for the Metropolis and Others Ex Parte Pinochet (On Appeal from a Divisional Court of the Queen's Bench Division). Decisão de 24 de março de 1999. International Legal Materials, p. 591-663, 1999/38. 
mesma da convenção de 1984: a repressão à tortura. ${ }^{58}$ Ademais, os lordes salientaram a natureza de jus cogens da norma que proíbe a prática da tortura no Direito Internacional.

O alcance desse precedente para o direito das imunidades dos exgovernantes permanece, contudo, deveras obscuro, porquanto a ausência de imunidade de Pinochet decorreu antes das disposições específicas da Convenção sobre a tortura, de 1984, que de uma norma consuetudinária geral. Nesse caso em particular, a invocação do fundamento convencional reduziu sobremaneira as acusações que pesavam sobre o exchefe de Estado chileno, visto que a ausência de imunidade foi reconhecida apenas com relação aos atos posteriores à data da ratificação pelo Reino Unido da Convenção de $1984-8$ de dezembro de $1988 .^{59}$

A doutrina avançou, outrossim, outros argumentos para excluir a imunidade dos ex-governantes quando eles estão implicados em crimes internacionais, mesmo quando tais crimes configurem atos de função. A esse respeito, C. Dominicé afirma que as regras internacionais sobre os crimes devem preponderar sobre as que disciplinam as imunidades dos governantes. ${ }^{60}$

Convém observar, porém, que essa visão sobre os limites das imunidades dos ex-governantes não parece ter sido acolhida pela Corte Internacional de Justiça, que reafirmou a distinção clássica entre atos de função e atos privados. Em um obiter dictum da decisão do Caso Yerodia, a Corte assinalou que, em se tratando de atos cometidos no exercício de suas funções, os ex-governantes dispõem de uma imunidade penal absoluta pelos seus atos de função. ${ }^{\circ 1}$ A significação desse obiter dicım permanece, contudo, incerta, visto que a Corte não precisou se os crimes internacionais estão compreendidos na noção de atos de função.

s8 "Therefore the whole elaborate structure of universal jurisdiction over torture committed by officials is rendered abortive and one of the main objectives of the Torture Convention--to provide a system under which there is no safe haven for torturers--will have been frustrated. In my judgment all these factors together demonstrate that the notion of continued immunity for ex-heads of state is inconsistent with the provisions of the Torture Convention. For thesc reasons in my judgment if, as alleged, Scnator Pinochet organised and authorised torture after 8 December 1988. he was not acting in any capacity which gives rise to immunity ratione materiae because such actions were contrary to international law, Chile had agreed to outlaw such conduct and Chile had agreed with the other parties to the Torture Convention that all signatory states should have jurisdiction to try official torture (as defined in the Convention) even if such torture were committed in Chile" Lord Browne-Wilkinson. Judgment Regina v. Bartle and the Commissioner of Police for the Metropolis and Others Ex Parte Pinochet Regina v. Evans and Another and the Commissioner of Police for the Metropolis and Others Ex Parte Pinochet (On Appeal from a Divisional Court of the Queen's Bench Division), op. cit., p. 581 e s.

59 Como é sabido. o periodo mais negro da repressão chilena é anterior a essa data. Assim. a Câmara dos Lordes reconheceu a imunidade de Pinochet com relação às acusaçōes mais sérias de tortura que pesavam sobre ele.

60 Veja-se, por exemplo, DOMINICÉ (C.), op. cit., p. 297-308.

61 Affaire du mandat d'arrêt du 11 avril 2000 , op. cit., § 61 . 
Diante das imprecisões e das contradições das decisões das jurisdições nacionais e internacionais em um curto período de tempo, segue-se que não se pode dizer, com exatidão. qual é o estado atual do Direito Internacional sobre essa matéria.

\subsubsection{A ausência de influência da criminalização dos atos relacionados à função de governante sobre a imunidade ratione personue dos governantes em exercício}

Quando os governantes estão no exercício de suas atribuições oficiais, a imunidade penal ratione personae impede que eles sejam objeto de todo e qualquer processo penal movido em uma jurisdição estrangeira, qualquer que seja o motivo de tal processo. Por conseguinte, contrariamente ao que sucede com a imunidade ratione materiae dos ex-governantes, as características do crime - se ele foi cometido antes ou depois do início do exercício das funções de governante ou ainda se ele faz parte da categoria de atos de função ou de atos privados - não têm qualquer importância para delimitar a extensão da imunidade ratione personae dos governantes em exercício.

A natureza absoluta de que se reveste essa imunidade foi, no entanto, posta em causa pela inovação representada pela criminalização pelo Direito Internacional de determinadas condutas. Com efeito, o desenvolvimento do Direito Internacional penal reflete a firme reprovação que determinadas condutas suscitam no seio da comunidade internacional. ${ }^{62}$ Por essa razão, sustenta-se que as normas sobre os crimes internacionais devem primar sobre as imunidades dos governantes em exercício, quando eles são acusados de haverem cometido crimes internacionais. Para sustentar tal tese. sublinhamse a natureza de jus cogens das normas de Direito Internacional acerca dos crimes internacionais e a primazia da proteção dos direitos humanos na ordem jurídica atual. ${ }^{63}$

O Caso Yerodia foi a ocasião em que se testou a validade dessa ordem de argumentos, visto que o mandado de detenção belga fundava-se nos crimes de guerra e contra a humanidade de que o então ministro das Relações Exteriores congolês era acusado. A Bélgica, para sustentar a legalidade do mandado. invocou precisamente a gravidade particular dos crimes atribuidos a Yerodia.

Essa tese foi admitida pelo juiz Awn Al-Khasawneh em sua opinião dissidente. Para Al-Khasawneh, o combate efetivo aos crimes internacionais adquiriu um

${ }_{62}$ A esse propósito, Alain Pellet observa que os crimes internacionais são "particulièrement odieux, qui choquent la conscience de l'humanité tout entière et dont la répression intéresse la communauté internationale dans son ensemble." PELLET (A.). Présentation de la première partie. In : ASCENSIO (H.), DECAUX (E.) e PElleT (A.) (eds). Droit International Pénal. Paris, E. Pedone, 2000. p. 85.

63 Essa mesma sorte de argumentos, conforme já visı, é utilizada para negar a imunidade ratione materiae aos ex-governantes no caso de crimes intemacionais. Sobre esse tema, ver notadamente BORGHI (A.), op. cit. p. 293 es. 
caráter de jus cogens e deve, pois, prevalecer sobre as regras acerca das imunidades." A juiza ad hoc Van Den Wyngaert expôs uma fundamentação análoga em sua opinião dissidente. ${ }^{05}$

Essa linha de argumentação não foi acolhida, contudo, pela Corte Internacional de Justiça. Aliás. ela sequer menciona em seu acórdão a questão do jus cogens. Em sua decisão, a Corte adstringiu-se a reafirmar a regra clássica da imunidade penal absoluta dos governantes em exercício e a assinalar que não há uma exceção consuetudinária a tal imunidade, ainda que os crimes que lhes sejam imputados sejam crimes de guerra ou crimes contra a humanidade. ${ }^{66}$

Essa linha argumentativa fundada sobre a noção de jus cogens foi igualmente criticada por J. Verhoeven. Para Verhoeven, inexiste conflito entre as regras que tratam das imunidades e aquelas que reprimem os crimes internacionais. A imunidade, acrescenta ele, é uma questão de Direito Processual e não constitui, portanto, um obstáculo à responsabilização individual dos autores de crimes internacionais - um tema de direito substancial. ${ }^{67}$

Essa crítica de Verhoeven demonstra que o estudo das imunidades na perspectiva da criminalização de determinados atos associados à função de governante não é suficiente para apreciar o lugar ocupado pelas imunidades dos governantes na ordem jurídica contemporânea. Faz-se necessário, ainda, estudá-las sob o pano de fundo da afirmação da responsabilidade penal individual dos governantes.

2.2 A imunidade diante da responsabilidade penal individual dos governantes

Não é raro caracterizar-se o Direito Internacional como uma ordem juridica essencialmente ou exclusivamente interestatal. Disso resulta que os Estados foram por muito tempo considerados os únicos sujeitos de direito que podiam ser responsabilizados pelas violações ao Direito Internacional. ${ }^{68}$

Assim, a presença de regras jurídicas internacionais que atribuem aos individuos, em particular aos governantes, uma responsabilidade penal individual, representou uma inovação substancial para o Direito Internacional $(2.2 .1),{ }^{69}$ cuja repercussão sobre as imunidades dos governantes deve ser apreciada (2.2.2).

\footnotetext{
4. Upinion dissidente du juge Awn Al-Khasawneh, Affaire du mandat d'arrêt du II avril 2000, op. cit., \$7.

65 Opinion dissidente de Mme Van Den Wyngaert. Affaire du mandat d'arrët du II avril 2000. op. cit, $\$ 28$.

* Affaire du mandat d’arrêt du 11 avril 2000, op. cit, $\S 58$.

67 VERHOEVEN, J. op. cit., p. 128-130.

68 "La responsabilité internationale est essentiellement conçue comme une institution juridique jouant d'un Etat a Etat, même si depuis la reconnaissance de leur personnalité juridique internationalc, la responsabilité des organisations internationales obéit en principe aux mêmes régles". DUPUY, P. M. Droit International Public. Paris: Dalloz, 1998. p. 412-413.
} 
2.2.1 A responsabilidade penal dos governantes por crimes internacionais diante das jurisdições internacionais

2.2.1.1. Os obstáculos aparentes à concretização da responsabilidade penal dos governantes nas jurisdições internacionais

Após a segunda guerra mundial, procurou-se punir os indivíduos que organizaram, planejaram e ordenaram a execução de crimes internacionais pela utilização do aparelho do Estado. Daí a importância que assumiu, desde essa época, a responsabilidade penal e individual dos governantes, tendo em vista o papel preponderante por eles exercido no seio do aparato estatal..$^{70}$

No que concerne ao direito das imunidades, essa afirmação da responsabilidade penal dos governantes chocava-se, à primeira vista, com dois obstáculos: as disposições das constituições nacionais que atribuíam imunidades aos governantes $^{71}$ e as normas clássicas do Direito Internacional sobre as imunidades dos governantes em exercício. Esses entraves pareciam tanto mais dificeis a serem superados quanto os atos de que os governantes eram acusados estavam relacionados ao exercício de suas funções públicas.

Em se tratando do primeiro entrave, deve-se lembrar da norma consuetudinária internacional consoante a qual os sujeitos de Direito Internacional não podem se valer de regras internas para violar o Direito Internacional e para se subtraírem da sua responsabilização por essas violações. ${ }^{72}$ Com efeito, são as normas internacionais que definem a responsabilidade penal dos governantes. pelo que eles não podem invocar a sua imunidade conferida pelo direito interno para eximirem-se dessa responsabilização.

69 Para R. Maison, trata-se de "un reversement radical dans les techniques de responsabilité internationale." MAISON (R.). Immunités et tribunaux pénaux internationaux. In : VERHOEVEN J. (ed.). Le droit international des immunités: contestation ou consolidation?. Paris, L.G.D.J., 2004. p. 193.

70 Uma primeira tentativa de responsabilizar internacionalmente os governantes por seus atos sucedeu após o fim da primeira guerra mundial. O art. 227 do tratado de Versalhes previa a instituição de um tribunal internacional ad hoc para julgar o imperador alemão Guilherme II por crimes cometidos durante o conflito. Todavia, o Governo holandês, pais em que Guilhcrme II havia se exilado, recusou-se a extraditalo. Em consequiência, esse artigo do tratado de Versalhes não foi levado a efeito. BORGHI, (A.), op. cit. 211 es.

11 As disposições das constituições nacionais que tratam dessa imunidade são ainda hoje bem numerosas. Sobre o assunto, ver notadamente BEAUD (O.). L'immunité du chef de l'Etat en droit constitutionnel et en droit comparé. In: VERHOEVEN J. (ed.). Le droit intemational des immunités: contestation ou consolidation?. Paris, L.G.D.J., 2004. p. 149-188.

72 Veja-se, a esse respeito. 0 ant. 32 dos artigos da Comissão de Direito Internacional sobre a responsabilidade internacional do Estado por atos ilicitos. CRAWFORD (J.). The intemational law commission's articles on state responsibility: introduction, text and comments. Cambridge, Cambridge University Press, 2002. p. 207-208. 
Quanto ao segundo óbice, ele pôde ser superado em razão da natureza internacional das jurisdições que foram criadas após o segundo grande conflito mundial. Como sublinha J. Verhoeven, a imunidade tem sentido apenas diante de um juiz estrangeiro, ${ }^{73}$ vale dizer, diante do imperium de um outro Estado. É essa submissão do governante à jurisdição de um outro Estado que prejudica o livre exercício da função de governante e ofende a soberania estatal.

A função das jurisdições internacionais, por sua vez. consiste precisamente em julgar os Estados e os seus órgãos, o que impede que eles possam invocar a sua imunidade a fim de subtrair-se ao poder do juiz internacional. ${ }^{14}$ A esse respeito, cumpre sublinhar que o poder dos tribunais internacionais não provém da soberania de um outro Estado, mas das normas de Direito Internacional a que os Estados estão sujeitos.

Assim, os dois obstáculos acima referidos à efetivação da responsabilidade penal dos governantes diante das jurisdições internacionais eram tão-somente aparentes. Seja, porém, como for. os estatutos dos tribunais internacionais precisam que os governantes não podem se valer de suas imunidades diante dessas jurisdições. " Por conseguinte, as imunidades dos governantes não constituiram um óbice à efetivação da responsabilidade penal dos governantes pelos tribunais internacionais.

\subsubsection{O alcance limitado da prática das jurisdições internacionais}

A instituição de tribunais internacionais para julgar os governantes foi, contudo, muito episódica. Após Nuremberg, o Direito Internacional Penal passou, na expressão de Alvaro Borghi, ${ }^{76}$ por um período de hibernação. Foi somente a partir da década de 90 que as jurisdições penais internacionais ganharam um novo impulso.

É necessário, todavia, observar que os tribunais penais intemacionais ad hoc são ainda raros na cena internacional e têm a sua competência muito restringida." Além disso, a sua criação depende de uma decisão do Conselho de Segurança da ONU e está, assim, submetida às contingências políticas inerentes ao funcionamento desse órgão.

23 VERHOEVEN, J. op. cit., p. 5.

24 J. Verhoeven observa que "il n'y a d'abord pas à contester la compétence de principe du juge institué dans l'ordre juridique international pour commettre les litiges qui mettent en cause un Etat souverain ou ses agents, auquel cc dernier est nécessairement 'soumis' alors qu'il ne l'est pas naturellement à un juge étranger." VERHOEVEN (J.), op. cit., p. 90.

75 Sobre esse assunto, ver BORGHI (A.), op. cil, p. 251 e s.

76 BORGHI, A. op. cit., p. 251 es.

77 Veja-se, por exemplo, o caso do Tribunal Penal Intcrnacional para a ex-luguslávia, cuja competência adstringe-se aos crimes internacionais cometidos no território da ex-lugoslávia. 
Quanto à Corte Penal Internacional, ainda é muito cedo para apreciar a sua contribuição para a efetivação da responsabilidade penal dos governantes. Aliás, de acordo com o seu estatuto, se os governantes não podem se valer de sua imunidade diante da Corte. os Estados continuam obrigados a obedecer as imunidades previstas no Direito Internacional. Essas imunidades podem impedir a entrega à Corte dos governantes que estejam no território de um Estado estrangeiro, o que pode dificultar o funcionamento efetivo desse novo tribunal internacional. ${ }^{78}$ Ademais, a Corte não é competente para julgar os crimes anteriores à sua instituição e seu estatuto prevê que os Estados continuam sendo os principais responsáveis pela punição dos crimes internacionais. $\mathrm{A}$ isso se acresce que um número substancial de Estados ainda não ratificou a Convenção de Roma que prevê a instituição do tribunal, notadamente os EUA.

Em razão dos fatos acima apontados, a efetivação da responsabilidade penal dos governantes pelos tribunais internacionais tem sido muito restrita na prática internacional. Assim, a responsabilidade penal individual dos governantes foi afirmada pelo Direito Internacional ${ }^{79}$ sem que os meios e as condições adequadas fossem instituídos para que ela fosse efetivada.

\subsubsection{A questão da contribuição da prática dos tribunais internacionais para a} imunidade dos governantes em exercício diante dos juízes estrangeiros

\subsubsection{A rejeição pela C.I.J. de uma exceção consuetudinária à imunidade dos governantes em exercício no caso de crimes internacionais}

Alguns autores viram na cristalização do preceito da responsabilização individual dos governantes e na prática dos tribunais internacionais desde Nuremberg um ponto de inflexão decisivo no direito das imunidades: a emergência de uma exceção consuetudinária às imunidades dos governantes em caso de crimes internacionais. ${ }^{80}$

78 Veja-se, a esse respeito, o art. 98 do estatuto da Corte Penal Internacional.

79 "The idea that individuals who commit international crimes are intemationally accountable for them has now become an accepted part of intemational law. Problems in this area--such as the non-existence of any standing international tribunal to have jurisdiction over such crimes, and the lack of agreement as to what acts are internationally criminal for this purpose--have not aflected the general acceptance of the principle of individual responsibility for international crimenal conduct. (...) It can no longer be doubted that as a matter of general customary international law a head of state will personally be liable to be called to account if there is sufficient evidence that he authorised or perpetrated such serious international crimes" WATTS, A. op. cit, p. 82.

${ }_{80}$ Esse raciocinio é explicitado pelo art. $7^{\circ}$ do projeto de crimes contra a paz e contra a stgurança da humanidade: "The absence of any procedural immunity with respect to prosecution or punishment in appropriate judicial proceedings is an essential corollary of the absence of any substantive immunity or defence. It would be paradoxical to prevent an individual from invoking his official position to avoid 
Essa questão adquiriu especial importância, após a consolidação da chamada competência universal a qual permite que o juiz nacional conheça de crimes internacionais cometidos no estrangeiro, sem que haja um liame de conexão entre o crime e o Estado do foro. ${ }^{81}$

Nos termos dessa tese da exceção consuetudinária, pode-se depreender da ausência de imunidade dos governantes em face dos tribunais internacionais e de sua responsabilidade penal individual, a ausência de imunidade diante dos tribunais estrangeiros em processos envolvendo crimes internacionais. ${ }^{82}$ Para fundar tal argumento, afirma-se que os estatutos dos tribunais internacionais não restringiram o preceito da ausência de imunidade aos processos movidos perante as jurisdições internacionais. Nesse sentido, em se tratando de crimes internacionais, os governantes em exercício não disporiam de nenhuma imunidade diante de qualquer tipo de jurisdição, seja ela nacional ou internacional..$^{83}$

No caso Yerodia. a Corte Internacional de Justiça rejeitou nitidamente essa linha argumentativa: para ela, a prática dos tribunais internacionais não é pertinente para se estabelecer a imunidade de que os governantes em exercício dispõem diante das jurisdições estrangeiras. ${ }^{84}$ Deveras, a substancial diferença de natureza entre uma jurisdição internacional e uma estrangeira constitui um sério óbice para se deduzir da ausência de imunidade diante da primeira a mesma inexistência de imunidade em face da segunda. A Corte asseverou também que inexiste uma prática dos Estados que seja suscetível de embasar uma exceção consuetudinária à imunidade dos governantes em função por crimes internacionais. ${ }^{85}$

responsibility for a crime only to permit him to invoke this same consideration to avoid the consequences of this responsibility." Apud. Opinion dissidente du juge Awn Al-Khasawneh. Affaire du mandat d'arrit du 11 avril 2000, op. cit, § 5. Veja-se, também, BORGHI, A. op. cit.

${ }^{81}$ Como observa Pierre-Marie Dupuy, os dois conceitos, embora distintos, estão estreitamente relacionados: "or, encore une fois, même si le problème des immunités de juridiction des responsables de la politiquc d'Etat et celui de la compétence universelle sont deux questions bien distinctes. I'admission élargie de la seconde conditionnera dans une grande mesure la réduction effective du champ d'application de la première" DUPUY, P. M. Crimes et immunités, ou dans quelle mesure la nature des premiers empêch. l'exercice des seconds. Revue Génerale de Droil International Public, p. 294. 1999/2.

82 Menciona-se com frequência, sobre isse assunto. a seguinte declaração do tribunal de Nuremberg: "le principe du droit intemational qui, dans certaines circonstances. protège les représentants d'un Etat, ne peut s'appliquer aux actes condamnés comme criminuls par le droit international. Les auteurs de ces actes ne peuvent invoquer leur qualité officielle pour se soustraire à la procédure normale ou se mettre à l'abri du chàtiment." Apud. DUPUY, P. M. op. cit., p. 290-291.

83 Veja-se, a esse respeito, BORGHI, A. op. cit. p. 211 es.

8. Essa mesma posição foi defendida por Michel Cosnard: "Ainsi. contrairement à ce qui est par ailleurs aflirmé, l'existence d'une juridiction pénale internationale $n$ 'exclut pas l'immunité mais au contraire cantonne son application à l'activité des juges étatiques." COSNARD (M.). op. cit.. p. 205-206.

35 A esse respeito, convém ressaltar que no caso Pinochet alguns lordes afirmaram, a titulo de obirer dictum. que a imunidade ratione personae dos governantes em exercicio é absoluta, mesmo quando eles sãu acusados do crime de tortura. Veja-se, por exemplo, o voto de Lord Browne-Wilkinson. Judgment - Regina 
Assim, mesmo reconhecendo que a qualidade de ministro das Relações Exteriores de Yerodia não o eximia de sua responsabilidade penal individual. a Corte reafirmou que ele dispõe de uma imunidade penal absoluta diante das jurisdições de outros paises. A esse propósito, a Corte observou que a responsabilidade penal individual é um conceito distinto da imunidade: enquanto que a primeira consiste em um tema de direito material, a segunda pertence ao direito processual. ${ }^{86}$

A Corte assinalou ainda que as imunidades nada mais são que um obstáculo processual à ação penal movida em face de um juiz estrangeiro. Nesse sentido, observou a Corte, as imunidades podem impedir ações penais durante um certo período e com relação a determinados crimes. Por outro lado, ainda de acordo com a Corte, a imunidade em nada prejudica a norma de Direito Internacional Penal que estabelece a responsabilidade individual dos governantes. ${ }^{87}$ Por isso, concluiu a Corte, a imunidade dos governantes em exercício diante do juiz estrangeiro não é sinônimo de impunidade.

\subsubsection{As dificuldades atuais para a efetivação da responsabilidade penal dos governantes em excrcício}

Após haver distinguido a imunidade dos governantes da sua impunidade. a C.I.J. fez alusão a quatro possibilidades de efetivação da responsabilidade penal dos governantes sem que o preceito clássico da imunidade diante das jurisdições estrangeiras seja posto em causa.

Em um primeiro momento, a Corte assinalou que inexiste nenhuma norma de Direito Internacional que impeça o governante de ser julgado pelo seu próprio país. Além disso, o Estado pode renunciar à imunidade de que beneficia o seu governante, o que tornará possível o seu julgamento por uma jurisdição estrangeira.

Em uma terceira hipótese, observou a Corte, o governante poderá ser submetido a uma jurisdição estrangeira, quando deixar as suas funções, visto que a imunidade de que dispõe na qualidade de ex-governante é limitada. Por fim, a Corte fez alusão às jurisdições penais internacionais as quais podem, quando competentes, julgar os governantes, estejam eles no exercício de suas funções ou não. ${ }^{88}$

v. Bartle and the Commissioner of Police for the Metropolis and Others Ex Parte Pinochet Regina v. Evans and Another and the Commissioner of Police for the Metropolis and Others Ex Parte Pinochet (On Appeal from a Divisional Court of the Queen's Bench Division), op. cit, p. 581 e s.

86 Aflaire du mandat d'arrèt du II avril 2000, op. cit., $\$ 58.59,60$.

8? Do mesmo modo, J. Verhoeven laz, a distinção entre imunidade e impunidade: "Elle (l'immunite) n’impliquc aucunement que son bénéficiaire ne soit pas responsable de ces actes, éventuellement criminel, qui lui sont reprochès; elle signifie seulement que tribunal devant lequel cette responsabilité devant lequel cette responsabilité est mise en cause ne peut pas en connaître." VERHOEVEN (J.), op. cit., p. 91.

88 Affaire du mandat d'arrèt du 11 avril 2000, op. cit., $\$ 61$. 
Malgrado essa distinção feita pela Corte entre impunidade e imunidade. parece-nos imperioso sublinhar o profundo divórcio entre, de um lado, a formulação teórica dessas quatro hipóteses e, de outro, as possibilidades reais de sua eletiva concretização.

Em se tratando das duas primeiras hipóteses, a influência que os governantes exercem sobre os seus próprios paises impedem que elas sejam levadas a efeito. Ademais, os governantes podem implementar em seus próprios países mecanismos jurídicos que lhes permitem perpetuar essa influência mesmo após terem deixado o poder. ${ }^{89}$ Assim, por exemplo, leis de anistia podem ser instituídas com o objetivo de assegurar a impunidade dos crimes praticados pelos ex-governantes. ${ }^{90}$ Essa proteção nacional é, também, uma garantia contra a extradição potencial dos exgovernantes em ações penais movidas diante das jurisdições estrangeiras. A propósito, a própria Corte foi ambígua em relação à extensão das imunidades de que os exgovernantes desfrutam. No que se refere à quarta hipótese vislumbrada pela Corte. os limites da ação das jurisdições penais internacionais já foram salientados. ${ }^{91}$

São, aliás, as grandes falhas dessas quatro possibilidades de efetivação da responsabilidade penal dos governantes que incitou as jurisdições nacionais a quererem julgar os governantes estrangeiros, sob o fundamento da competência universal. Nesse sentido, o julgamento de governantes em exercício por jurisdições estrangeiras sob a base da competência universal seria uma solução paliativa à espera da instituição de uma jurisdição internacional efetiva. ${ }^{92}$

av Oexemplo de Pinochel é mais uma vez muito ilustrativo. Mesmo após ter deixado o posto de chefe de Estado. Pinochet foi durante vários anos o mais alto comandante do exército chileno. Foi apenas após o julgamento da Câmara dos Lordes que sua influència sobre a política chilena decresceu e sua imunidade pôde ser contestada na justiça chilena. Sobre o assunto, ver La Cour suprême du Chili donne son feu vert au jugement de Pinochet. Le monde, 06 janeiro de 2005. p. 7.

90 Nos paises da América Latina, os exemplos de leis de anistia são notoriamente muito numerosos. Sobre o assunto, ver BORGHI, A. op. cit., p. 179 es.

91 Esse divórcio foi também sublinhado pelos juizes Higgins, Kooijmans et Buergenthal em sua opiniāo conjunta: "After having emphasized - and we could nol agree more - that the immunity from jurisdiction enjoyed by incumbent Ministers for Foreign Affairs does not mean that they enjoy impunity in respect of any crimes they might have committed (para. 60), the Cour goes on to say that these immunities do not represent a bar to criminal prosecution in certain circumstances (para. 61). We feel less than sanguine about examples given by the Court of such circumstances. The chance that a Minister tor Foreign Affairs will be tried in his own country in accordance with the relevant rules of domestic law or that his immunity will be waived by his own State is not high as long as there has been no change of power, whereas the existence of a competent international criminal court to initiate criminal proceedings is rare; moreover. it is quite risky to expect too much of a future international criminal coun in this respect. The only credible altemative therefore seems to be the possibility of starting proceedings in a foreign court after the suspected person ceases to hold the oftice of Foreign Minister. This altemative, however, can also be easily forestalled by an uncooperative government that keeps the Minister in office for an as yet indelerminate period". Joint Separate Opinion of Judges Higgins, Kooıjmans and Buergenthal, op. cit., $\$ 78$.

?. COSNARD. M. up. cit. p. 268. 
O Caso Yerodia. no entanto, pôs fim à possibilidade de os Estados fazerem uso legalmente dessa solução paliativa, ${ }^{93}$ porquanto a C.I.J. condenou, claramente, essa forma de "unilateralismo judiciário" 94 É por esse motivo que essa decisão foi considerada um retrocesso no combate à impunidade em matéria de crime internacional. A bem dizer, as insuficiências atuais dos meios legais de efetivação da responsabilidade penal dos governantes podem conduzir a uma impunidade de facto dos governantes que tenham cometido crimes internacionais.

Por outro lado, deve-se igualmente observar que a decisão da C.I.J. pôs fim aos riscos apreciáveis desse unilateralismo judiciário. Por conta do grande número de jurisdições nacionais e de governantes na comunidade internacional, havia o claro risco de uma banalização das ações penais intentadas contra os governantes em exercício, o que poderia tornar instáveis as relações internacionais.

Esse risco é tanto mais presente quanto esse unilateralismo judiciário pode dar lugar a processos penais, motivados por considerações puramente políticas, especialmente $\mathrm{um}$ paises cujo Poder Judiciário não desfruta de garantias institucionais contra a ingerência do Poder Executivo no exercicio de sua atividade jurisdicional. Podese citar, a título de exemplo, a condenação, de 21 de setembro de 2000, dos chefes de Estado da OTAN por um tribunal de Belgrado por atos cometidos na ex-Iugoslávia pelos Estados membros dessa organização. ${ }^{9 \varsigma}$

Ademais, no quadro desse unilateralismo judiciário, há uma estreita relação entre o poder dos Estados nas relações internacionais e possibilidade de existirem processos penais contra os seus governantes, sob o fundamento da competência universal. A esse respeito, J. Verhoeven observa que é dificil de imaginar que os presidentes em exercício da Rússia e dos EUA sejam julgados pela justiça belga com base na famosa lei sobre a competência universal. Para Verhoeven, somente os chefes de Estado de pequenos países seriam submetidos a essa "justiça universal" 9

${ }^{93}$ A esse respeito, são muito significativas as modificações à lei belga sobre a competência universal introduzidas apús o caso Yerodia e as pressões diplomáticas. notadamente norte-americanas, sofridas pela Bélgica por conta dessa lei. Dentre essas modificaçōes. destacam-se precisamente as disposições sobre as imunidades dos governantes em exercicio. Essas disposições proibem processos penais contra os chefes dc Estado e de governo, o ministro das Relações Exteriores que estejam em função e outras pessoas, cuja imunidade é reconhecida pelo Direito Intemacional. Além disso, os artigos acerca da competência universal foram substancialmente modificados. Sobre o tema, ver notadamente RATNER, R. Belgim's War Crimes Statute: a post-modern. American Journal of International Law, p. 888-897, 2003/97.

Q4 COSNARD. M. op. cit. p. 268.

9) De acordo com Michel Cosnard. esse é o único exemplo de condenação penal por um juiz estrangeiro de um chefe de Estado em exercicio. COSNARD, M. op. cil., p. 230.

96 VERHOEVEN, J. Exposé préliminaire. Annuaire du Institut de Droit International, Paris, Pedone, 20002001/69. p. 519-520. 
Por conseguinte, o combate à impunidade em matéria de crimes internacionais requer a instituição de jurisdições internacionais efetivas e não do unilateralismo judiciário. Até que haja a edificação de tais jurisdições, não se pode deixar de constatar a preponderância, na ordem jurídica internacional contemporânea, da proteção do livre exercicio da função de governante - que se funda ainda na idéia da soberania do Estado - sobre o combate efetivo contra as graves violações aos Direitos Humanos. ${ }^{97}$

São Paulo. dezembro de 2006.

\section{Referências}

ASCENSCIO, H. L'immunité internationale du chef d'Etat. La nouvelle lettre de la F.I.D.H., Paris, 2000/32, p. 24-25.

BEAUD. O. L'immunité du chef de l'Etat en droit constitutionnel et en droit comparé. In: VERHOEVEN, J. (ed.). Le droit international des immunités: contestation ou consolidation? Paris, L.G.D.J.. 2004, p. 149-188.

BIANCHI, A. Immunity versus Human Rights: The Pinochet Case. European Journal of International Law, 1999/10, p. 237-277.

BORGHI, A. L'immunité des dirigeants politiques en droit international. Genève, Helbing \& Lichtenhahn, 2003.

CASSESE, A. When May Senior State Officials be Tried for International Crimes? Some Comments on the Congo v. Belgium Case. European Journal of International Law, 2002/13, p. 853-873.

COSNARD, M. Les immunités de chef d’Etat. In: Société Française pour lc Droit International. Le chef d'Etat et le droit international. Paris, E. Pedone, 2002, p. 189-268.

CRAWFORD. J. The international law commission's articles on state responsibility: introduction. text and comments. Cambridge, Cambridge University Press, 2002.

DAVID, E. L’immunité des chefs d’Etats et de gouvernements étrangers en fonction accusés de violation graves de droit international humanitairc. Nouvelles du droit international humanitaire. Service de droit international de droit humanitaire de la croix rouge belge. Disponivel em: <http://www:croix-rouge.be/img/db/immunites crimes.pdf>. Acesso em: 06 jan 2006.

"7 A esse respeito. P.M. Dupuy fala do conflito entre "la logique du Lotus" e "la logique de Nuremberg" DUPUY. P. M. op. cil. p. 289-296. 
DECAUX, E. Les gouvernants. In: ASCENCI() (H), DECALX (F.) e PELLET (A.) (eds.). Droit International Pénal. Paris, E. Pedone, p. 183-196.

DI:CAUX, E. Le statut du chef d'Etat déchu. Annuaire Français de Droit International, 1980, p. $101-139$.

DOMINICE, C. Quelques observations sur l'immunité de juridiction pénale de l'ancien chef d`Etat. Revue Générale de Droit International Public, 1999/2. pp 297- 308

DUPUY, P. M. Crimes et immunités, ou dans quelle mesure la nature des premicrs empêche l'exercice des seconds. Revue Générale de Droit International Public, 1999/2, p. 289-296.

DUPUY, ,P. M. Droit international public. Paris, Dalloz, 1998.

JENNINGS (R.). The Pinochet Extradition Case in the English Courts. In: BOISSON DE CHAZOURNES. L; GOWLLAND-DEBBAS (ed.). The International legal system in quest of equity and equality = L'ordre juridique international, un système en quête d'équité et universalité: liber amicorum Georges Abi-Saab. Nijhoff, The Hague, 2001, p. 677-698.

KOVACS, P. La prononcé de la peine. In: ASCENCIO, H.; DECAUX, F.: PF,LLET, A. (eds). Droit International Pénal. Paris, E. Pedone, p. 841-848.

MAISON, R. Immunités et tribunaux pénaux internationaux. In: VERHOEVFN, J. (ed.). Le droit international des immunités: contestation ou consolidation?. Paris. L.G.D.J., 2004, p. 191-217.

OXMAM. B.; ORAKHELASHVILI. A. Arrest Warrant of 11 April 2000. American Journal of International Law, 2002/96, p. 677-683.

PANCRACIO, J. P. L'évolution historique du statut de chef d'Etat. In: Société Française pour le Droit International. Le chef d`Etat et le droit international. Paris, E. Pedone, 2002, p. 09-171.

PELLFT, A. Présentation de la première partie. In: ASCENSIO, H.; DECAUX, E.; PELLET, A. (eds). Droit International Pénal. Paris, E. Pedone, 2000, p. 85-88.

RATNF,R, R. Belgium 's War Crimes Statute: a post-modern. American Journal of International Law. 2003/97. p. 888-897.

SALMON. J. Immunités et actes de la fonction. Annuaire Français de Droit International, 1992, p. 314- 357 .

STERN. B. Immunities for Head ol State: Where do we stand?. [n: LATTIMER, M.; SANDS. P. (eds.). Justice for Crimes against Humanity. London. Hart Publishing, 2003, p. 73-106.

STERN, B. Tremblez. anciens dictateurs. Le Monde, 26 de março de 1999. p. 17. 
TOMUSCHAT. C. La cristallisation coutumière. In: ASCENCIO, H; DECAUX, E.; PELLET, A. (eds). Droit International Pénal. Paris, E. Pedone, p. 23-34.

TUNKS, M. Diplomats or Defendants? Defining the Future of Heads-of-State Immunity. Duke Law Journal, 2002/52. p. 551-681.

VERHOEVEN, J. Exposé préliminaire. Annuaire du Institut de Droit Intemational, 2000-200l/69. p. 444-53.

VERHOEVEN, J. Les immunités des organes des sujets de droit international. In: VERHOEVEN, J. (ed.). Le droit international des immunités: contestation ou consolidation? Paris, L.G.D.J., 2004, p. $61-146$.

VERHOEVEN, J. Mandat d'arrêt international et statut de ministre. Actualité et Droit International, mai 2002. Disponivel em: <http://www.ridi.org/adi/articles/2002/200205ver.htm>. Acesso em: 06 jan 2006.

VILLALPANDO, S. Laffaire Pinochet: beaucoup de bruit pour rien? Lapport au droit international de la décision de la chambre des Lords du 24 mars 1999. Revue Générale de Droit International Public. 2000/104, p. 393-427.

WATTS. A. The legal position in international law of heads of governments and foreign ministers. Recueil des Cours de l'Académie de Droit International de l'Haye, 1994/247. p. 19-129.

WIRTH, S. Immunity for Crimes? The ICJ's Judgement in the Congo v. Belgium Case. European Journal of International Law, 2002/13, p. 877-893.

Textos internacionais

Convenção contra a tortura e todas as formas de tratamento ou pena cruéis, desumanas ou degradantes de 10 de dezembro de 1984.

Convenção de Nova Iorque sobre as missões especiais de 8 de dezembro de 1969.

Convenção de Viena sobre as relações diplomáticas de 18 de abril de 1961.

Estatuto de Roma da Corte penal internacional de 17 de julho de 1998.

Resolução do Instituto de Direito Internacional sobre as imunidades de jurisdição e de execução do chefe de Estado e de govemo em Direito Internacional de 16 de agosto de 2001.

Jurisprudência internacional

Affaire du mandat d'arrêt du 11 avril 2000, Cour Internationale de Justice, arrêt du 14 février 2002. Disponivel em: 06/01/2006: www.icj-cij.org. Acesso em: 06/01/2006. 
Ben Aiad c. Bey de Tunis, Arrêt da la ('our d'Alger du 12 janvier 1914. Journal du Droit International, 1914/41, p. 1.291.

Consorts Duvalier et autres c. Etat haïtien et autres, Arrit de la Cour de Cassation, 29 mai 1990. Journal du Droit International, 1991/118, p. 139-140.

Jimenez. v. Aristeguieta (5th circuit). Federal Reporter, 313, $2^{\text {nd }}$ series, p. 547.

Judgment Regina v. Bartle and the Commissioner of Police for the Metropolis and others EX Parte Pinochet (on appeal from a Divisional ('ourt of the Queen's Bench Division) Regina v. Evans and another and the Commissioner of Police for the Metropolis and others EX Parte Pinochet (on appeal from a Divisional Cuurt of the Queen's Bench Division). Decisão de 25 novembro de 1998. International Legal Materials, 1998/37, p. 1302-1339.

Judgment Regina v. Bartle and the Commissioncr of Police for the Metropolis and Othurs Ex Parte Pinochet Regina v. Evans and Another and the Commissioner of Police for the Metropolis and Others Ex Parte Pinochet (On Appeal from a Divisional Court of the Queen's Bunch Division). Decisão de 24 março 1999. International Legal Materials, 1999/38, p. 581-663.

Republic of the Philippines v. Marcos, Federal Reporter, $818,2^{\text {tud }}$ series, p. 1.473. 